\title{
兵庫県南部地震における大阪府豊中市の地震動特性と被害集中に関する研究 STUDY ON GROUND MOTION CHARACTERISTICS AND CONCENTRATION OF DAMAGES IN TOYONAKA CITY, OSAKA DURING THE 1995 HYOGO-KEN NANBU EARTHQUAKE
}

\author{
山口陽司*，仲野一秀*，宮本 裕司** \\ Youji YAMAGUCHI, Kazuhide NAKANO and Yuji MIYAMOTO
}

\begin{abstract}
During the 1995 Hyogo-ken Nanbu earthquake, building damages concentrated in the southern part of Toyonaka city. Most of the damaged buildings were wooden houses. In this study, we evaluate the ground motions to clarify the cause of damages concentration in Toyonaka city. 2D FEM models of the deep underground are analyzed considering irregular structures by Uemachi fault running north-south of Toyonaka. The observed record at the surface near Toyonaka city was used to estimate the input motion. 1D nonlinear analyses of the surface soils are also carried out on the basis of boring data.
\end{abstract}

Keywords : 1995 Hyogo-ken Nanbu earthquake, Toyonaka city, Concentration of damages, Ground motions, Surface soil,

Deep irregular underground structure

1995 年兵庫県南部地震，豊中市，被害集中，地震動，表層地盤，深部不整形地盤構造

1. はじめに

1995 年に発生した兵庫県南部地震は、神戸市を中心とした広い地 域に甚大な被害をもたらした 1)。神戸市などの被災中心地域の被害 が注目される中、その周辺地域である大阪府においても、比較的多 くの被害が報告されている。大阪府の中でも特に豊中市においては、 北部と中部の地域に比べて南部の地域に建物の被害が集中した。南 部の地域が古い木造賃貸住宅の住宅地であったことや、軟弱地盤で あったことが、その原因であろうと指摘されている2)。しかし、ボ ーリング結果などの地盤データや地盤構造を考慮した地震応答解析 による詳細な検討は未だなされていない。

一方、大阪府では今後 30 年間の発生確率が $60 ７ 0 \%$ と非常に高く 切迫性が指摘される東南海・南海地震3)や、大阪府を南北に縦断す る上町断層帯の直下型地震による被害が懸念されている。今後起こ りうる地震に対する防災計画を行う上で、大阪府豊中市の南部地域 において兵庫県南部地震の際に建物の被害が集中した原因を究明す ることは、入力地震動の特性を把握し、地盤構造の違いを考慮した 被害予測や耐震設計を行う上で大変重要になる。

そこで本研究では、兵庫県南部地震の際に被害が集中した原因を 明らかにするため、大阪府豊中市の南部地域と、その比較対象とし て被害の少なかった中部地域を研究対象と寸る。この対象地域の地 盤モデルを作成する際、地表から工学的基盤位置までを表層地盤、 工学的基盤位置から地震基盤位置を深部地盤とする。地盤データと しては、表層地盤のモデル化に関西圈地盤情報データベース $(2010$ 年度版)4)を、深部地盤のモデル化に大阪堆積盆地 3 次元地盤構造モ
デル5を使用した。なお、表層地盤は 1 次元で、深部地盤は 2 次元 でモデル化する。地震応答解析では、対象地域近辺で兵庫県南部地 震の際に地表面で観測された地震記録を用いて地震基盤での地震動 を推定し、対象地域の地表面の応答を算定する。次に、算定した表 層地盤の応答から、木造住宅の被害集中地域の地震動特性を分析し、 被害集中原因について検討することが本論文の目的である。

\section{2. 兵庫県南部地震での豊中市の被害状況}

豊中市の地形・地質の特徵と兵庫県南部地震での豊中市の被害に ついて述べる。

\section{1 豊中市の地形・地質の特徵}

豊中市の地形は大きく次の 4 つに分類され、それぞれの地形を構 成する地質は以下のようになる 6)。なお、（ )内の地域は後に示寸図 1 の地域区分に対応している。

（1）丘陵地域(北部・東部・ニュータウン地域）

市域の東部から北部にかけての地域である。標高が概ね $30 \mathrm{~m}$ から $100 \mathrm{~m}$ と起伏量が大きいため、造成にあたっては切り土・盛り土を 行っている。ここの地層は、大阪層群と呼ばれる未固結堆積物(砂砅、 粘土、火山灰等)から構成されている。

(2)段丘地域(中部地域)

天竺川沿岸から千里川北岸部にかけての地域で、標高は概致 $10 \mathrm{~m}$ か ら $60 \mathrm{~m}$ である。この地域には豊中、岡町など市の中心部が位置して いる。段丘は丘陵地域より形成された時代が新しいため、谷は浅く、 勾配も緩やかで、段丘の縁の斜面を除いて非常に平坦になっている。
$*$ 大阪大学大学院工学研究科地球総合工学専攻 大学院生

** 大阪大学大学院工学研究科地球総合工学専攻 教授. 工博 
この段丘は、厚さ $10 \mathrm{~m}$ 程度のチャート・砂岩・貢岩の円碅(細〜中 礫)で構成されている。

(3)神崎川低地(南部地域)

阪急服部駅から南側にかけての地域で、標高は $4 \mathrm{~m}$ 以下である。大 阪湾や神崎川に運ばれた土砂が常時水面下の状況で堆積した平地で 地表下 $10 \mathrm{~m}$ から $20 \mathrm{~m}$ 付近まで沖積層(軟弱粘土層、砂層)が分布し ている。

(4)猪名川低地(西部地域)

大阪空港周辺から千里川沿いの地域で、標高は $4 \mathrm{~m}$ から $15 \mathrm{~m}$ である。 大阪空港へ続く平坦面は猪名川、千里川などが汇濫した際に堆積し た土砂からなり、神崎川低地のような地質の均一性、連続性はあま り見られない。

また豊中市域には、天竺川にほぼ並行する形で上町断層帯の北側 に位置する仏念寺山断層が南北に走っている。

\section{2 兵庫県南部地震での豊中市の被害}

兵庫県南部地震の際、兵庫県阪神地区に隣接する豊中市とその東 側に位置する吹田市は、表 1 に示すように大阪府内の市町村の中で 多くの被害が発生した ${ }^{6)}$ 。図 1 に豊中市の全・半壊建築物の分布を 示す。図 1 から市の南部にある服部地区や庄内地区に被害が集中し ていることがわかる。一方、市の北東部に位置する千里ニュータウ ン地区では被害が見られなかった。この地区における団地群には顕 著なひび割れが見当たらなく、一戸建て住宅においても屋根瓦の損 傷等の被害もなかった。また、北部と東部といった市の北半部の地 域においても特に目立った被害はなかった。被害の集中した南部の 地域では瓦のずれ、外壁の亀裂、屋根崩れ、家屋の傾き等様々な被 害があり、全般的に古い木造家屋の被害が多く見られた ${ }^{2)}$ 。表 2 に 南部の地域に位置する庄内地区と服部地区の木造家屋の被災状沉 7) を示す。一般木造家屋の全半壊率は、庄内地区で $11.1 \%$ 、服部地区 で $16.4 \%$ ある。また、一般木造家屋のうちで、古い木造賃貸住宅

表 1 大阪府市町村の被害状況 ${ }^{6)}$

\begin{tabular}{|c|c|c|c|c|c|c|c|}
\hline \multirow{3}{*}{ 市町村名 } & \multicolumn{3}{|c|}{ 人的被害 } & \multicolumn{4}{|c|}{ 住家の被害 } \\
\hline & 死者 & 苗佰 & 計 & 全壊流失 & 半壊 & 一部損壊 & 計 \\
\hline & 死者 & 貝偒 & 計 & 棟 & 棟 & 棟 & 棟 \\
\hline 大阪市 & 17 & 349 & 366 & 194 & 2,145 & 16,463 & 18,802 \\
\hline 吹田市 & 1 & 21 & 22 & 10 & 308 & 10,254 & 10,572 \\
\hline 豊中市 & 9 & 2,496 & 2,505 & 657 & 4,263 & 30,256 & 35,176 \\
\hline その他 & 3 & 715 & 718 & 34 & 511 & 30,920 & 31,465 \\
\hline 合計 & 30 & 3,581 & 3,611 & 895 & 7,227 & 87,893 & 96,015 \\
\hline
\end{tabular}

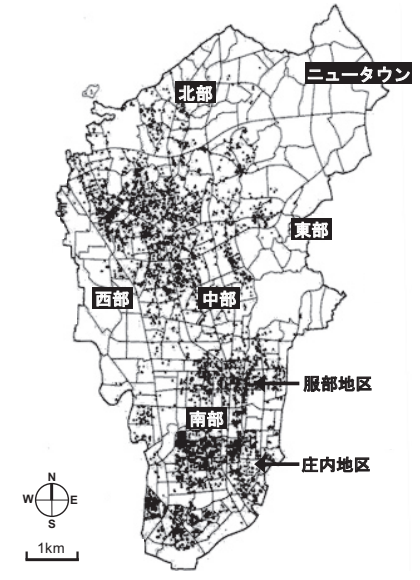

図 1 豊中市の全半壊建物分布 6
表 2 木造家屋被災状況 7)

\begin{tabular}{|c|c|c|c|}
\hline \multicolumn{2}{|r|}{ 家屋区分 } & 庄内地区 & 服部地区 \\
\hline 般 & 調查家屋棟数 (棟) & 3,564 & 2,040 \\
\hline $\begin{array}{l}\text { 木 } \\
\text { 造 }\end{array}$ & 全半壞棟数 (棟) & 395 & 334 \\
\hline 屋 & 全半壞率 (\%) & 11.1 & 16.4 \\
\hline 文 & 調査家屋棟数 (棟) & 303 & 140 \\
\hline $\begin{array}{l}\text { 化 } \\
\text { 住 }\end{array}$ & 全半壊棟数 (棟) & 125 & 58 \\
\hline 乇車 & 全半壊率 (\%) & 41.3 & 41.4 \\
\hline
\end{tabular}

注）一般木造家屋中には文化住宅も含む。 全半壞の判定基淮

全壊 : (1)延床面積の $70 \%$ 以上の損壊 (2)主要構造物(壁、柱、梁、屋根、階段) の被害額が $50 \%$ 以上

半壊 : (1) 延床面積の $20 \%$ 以上、 $70 \%$ 未満の損壊 (2)主要構造物の被害額が $20 \%$ 以上、 $50 \%$ 未満の損壊
である文化住宅の全半壊率は両地区とも $41 \%$ となる。南部の地域に 被害が集中した原因として、この地域が前項で述べた神崎川低地に 位置していて、神崎川低地を構成する軟弱な表層地盤の影響と、こ の地域が昭和 30 年代に急激な都市化によって形成され、古い木造 賃貸住宅が比較的多い過密住地であったことが考えられている2)。

\section{3. 研究対象地域と検討手法}

\section{1 研究対象地域}

前章で述べたように、兵庫県南部地震の際、豊中市の南部の地域 において建物の全・半壊被害が集中した。そのため、本研究では市 の中部から南部の地域 を研究対象とし、図 2 に示す 4 本の太線部で 切った地盤断面をモデ ル化し、北から model.A,B,C,OP とす る。 model.A,B,C,OP は深部地盤断面モデル である。さらに model.A,B,C 断面上の $\mathrm{A} 1, \mathrm{~A} 2, \mathrm{~B} 1, \mathrm{~B} 2, \mathrm{C} 1, \mathrm{C} 2$ の 6 地点において表層 地盤を 1 次元でモデル 化し、地表面の応答を 評価した。なお、上町

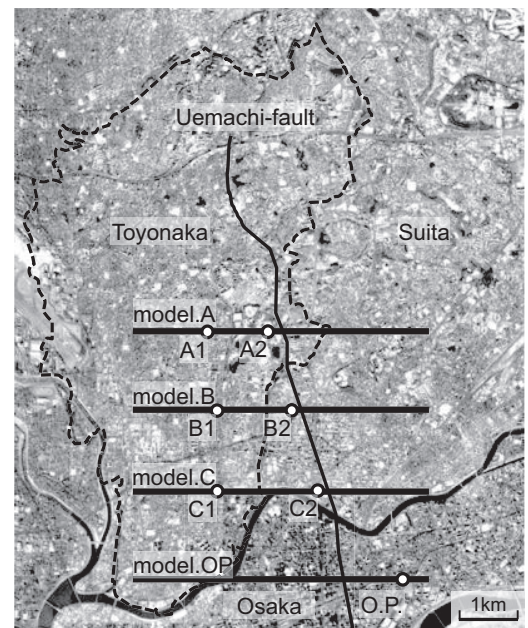

図 2 研究対象地域図
断層帯による深部段差構造の影響を考慮するため、隣接する吹田市 側に延長しており、長さ $5 \mathrm{~km}$ の東西方向断面モデルである。 model.A は図 1 の全半壊建築物分布が少ない地域を通るように切っ た断面である。一方、model.B,C は図 1 の全半壞建築物分布が集中 した地域の中心を通るように切った断面で、B1 地点は服部地区、 $\mathrm{C} 1$ 地点は庄内地区に位置する。また、後述の 4.4 節で検討する吹田 市南西部に位置する $\mathrm{B} 2$ と $\mathrm{C} 2$ の周辺地域においても、建物の全半 壞被害棟数が多かったことが吹田市の被害調查に報告されている ${ }^{8)}$ model.OP は、図 2 で「O.P.」と記した兵庫県南部地震の際に地表 面で地震観測された地点を通るように切った断面である。

\section{2 検討手法}

地表面の応答は図 3 に示す次のようなステップで算出した。まず、

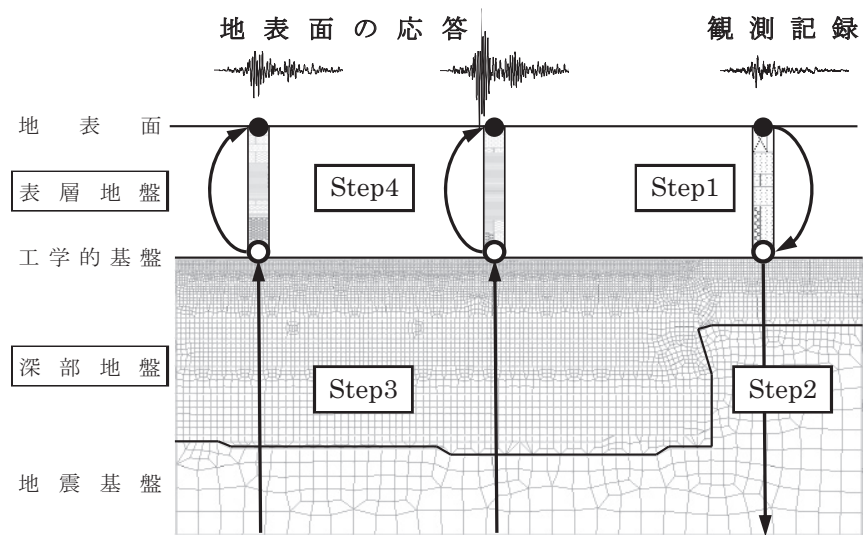

図 3 地表面応答算出の手順 
対象地域近辺で兵庫県南部地震の際に地表面で観測された記録を工 学的基盤位置での地震動に変換し(Step1)、さらに観測地点を通る深 部地盤断面モデルで上町断層帯による深部段差構造の影響を考慮し た逆応答解析から地震基盤位置での地震動を作成した(Step2)。作成 した地震基盤波を各深部地盤モデルに入力することで、工学的基盤 位置の応答を求めた(Step3)。そして、各地点の工学的基盤波を表層 地盤モデルに入力することで地表面の応答を求めた(Step4)。

\section{4. 深部地盤の応答評価}

\section{1 観測記録の逆応答解析}

図 2 で「O.P.」と記した JR 新大阪駅地点は、兵庫県南部地震の 際に対象地域に最も近い地表面で地震観測された地点である9 。ここ の地点の観測記録を用いて工学的基盤位置での地震動評価を行った。

\section{表 3 JR 新大阪駅地点の}

表層地盤モデル

\begin{tabular}{|c|c|c|c|c|}
\hline $\begin{array}{c}\text { 下端深度層厚 } \\
(\mathrm{m})\end{array}$ & $\begin{array}{c}\rho \\
(\mathrm{m})\end{array}$ & $\begin{array}{c}\text { 初期 } \mathrm{Vs} \\
(\mathrm{m} / \mathrm{s})\end{array}$ & 土質 \\
\hline 3.0 & 3.0 & 1.7 & 95 & 砂質士 \\
\hline 8.0 & 5.0 & 1.7 & 175 & 砂質士 \\
\hline 13.0 & 5.0 & 1.7 & 220 & 砂質士 \\
\hline- & - & 1.8 & 400 & 基盤 \\
\hline
\end{tabular}

表 4 土のせん断歪み依存性

\begin{tabular}{|c|c|c|c|}
\hline 土質 & $\begin{array}{c}\text { 基淮せん断 } \\
\text { 歪み } \\
(\%)\end{array}$ & $\begin{array}{c}\text { 最大減衰 } \\
\text { 定数 } \mathrm{h}_{\max } \\
(\%)\end{array}$ & $\begin{array}{c}\text { 減衰定数 } \\
\text { 下限値 } \\
(\%)\end{array}$ \\
\hline 粘性土 & 0.18 & 17.0 & 2.0 \\
\hline 砂質土 & 0.10 & 21.0 & 2.0 \\
\hline
\end{tabular}

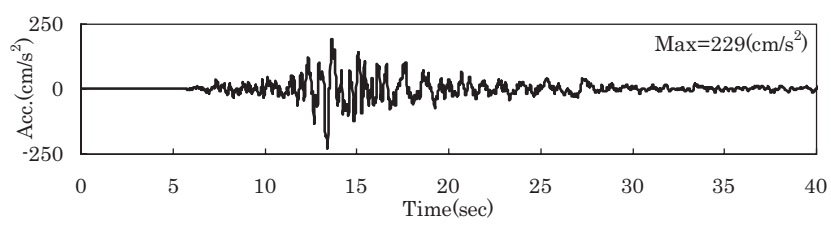

(a) $\mathrm{EW}$ 波

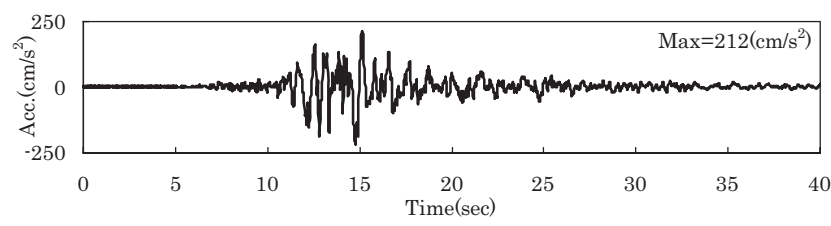

(b) NS 波

図 $4 \quad J R$ 新大阪駅地点の観測記録 (加速度波形)

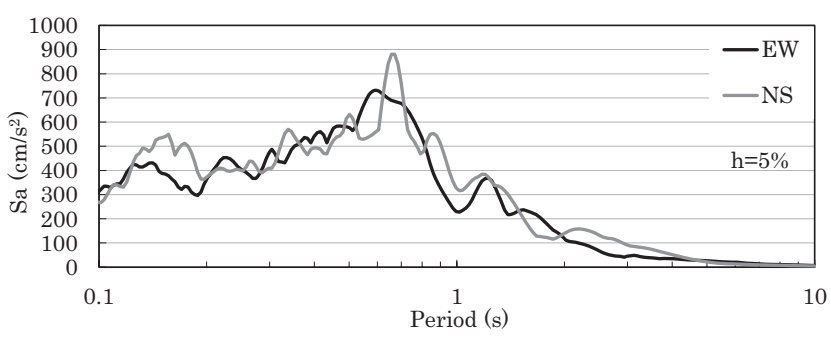

図 5 JR 新大阪駅地点の観測記録 (加速度応答スペクトル)

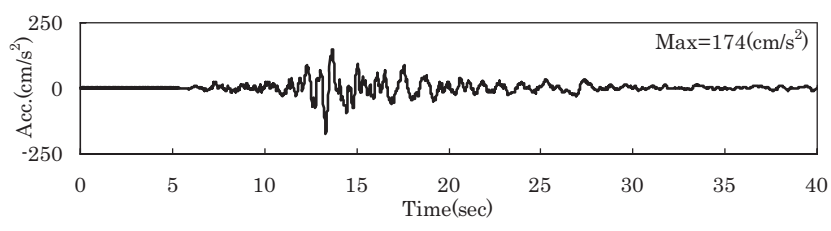

図 $6 \mathrm{JR}$ 新大阪駅地点の工学的基盤波( $\mathrm{EW}$ 波)
観測記録の水平方向の加速度波形を図 4 に、加速度応答スペクトル を図 5 に示す。図 4 と図 5 から $\mathrm{EW}$ 方向と NS 方向の波形とスペク トルに顕著な差が見られないことから、本検討では深部地盤モデル の東西方向断面に対して SV 波入力となる $\mathrm{EW}$ 方向の波を用いて検 討する。地盤データに収録されている JR 新大阪駅地点付近の柱状 図と $\mathrm{N}$ 值の深度分布 ${ }^{4}$ )をもとに表 3 に示す表層地盤モデルを作成 した ${ }^{10)}$ 。砂質土のせん断歪多依存性には、表 4 に示寸古山田・宮本 モデル 11)を用いている。作成した表層地盤モデルと地表面の観測記 録(図 4(a))を用いて、等価線形解析プログラム Shake で逆応答解析 を行い、工学的基盤位置での地震動 $\mathrm{W}_{\mathrm{OP}}(\mathrm{t})$ (図 6)に变換した(Step1)。

\section{2 深部地盤モデル}

図 2 に記した太線部の地盤断面において、深部地盤データ 5)を用 いて作成した 2 次元 FEM のメッシュ model. A,B,C,OP を図 7 に示 す。地震基盤は $\mathrm{Vs}=3200(\mathrm{~m} / \mathrm{s})$ 、工学的基盤は断層上盤で $\mathrm{Vs}_{\mathrm{s}}=400(\mathrm{~m} / \mathrm{s})$ 、下盤で $\mathrm{Vs}_{\mathrm{s}}=300(\mathrm{~m} / \mathrm{s})$ としてモデル化している。各層 の地盤物性值を表 5 に示す。減衰定数 $\mathrm{h}$ は文献 12),13) から $\mathrm{Vs}_{\mathrm{s}}=300 \sim 700(\mathrm{~m} / \mathrm{s})$ で $\mathrm{h}=3(\%) 、 \mathrm{Vs}_{\mathrm{s}}=800 \sim 1500(\mathrm{~m} / \mathrm{s})$ で $\mathrm{h}=2(\%) 、$ $\mathrm{Vs}=3200(\mathrm{~m} / \mathrm{s})$ で $\mathrm{h}=1(\%)$ と設定している。本検討では $5 \mathrm{~Hz}$ までの精 度を考えた解析を行うため、各層の要素のサイズは、最大 $5 \mathrm{~Hz}$ の波 が透過できるように波長の $1 / 4$ 以下の距離でメッシュ分割を行った。 解析モデルの底面は粘性境界、側面はエネルギー伝達境界とした。 作成した深部地盤モデルから、上町断層帯による段差の高さが model.A,B で約 600m、model.C で約 800m、model.OP で約 $900 \mathrm{~m}$ と南に向かって高くなっていることがわかる。

\section{3 地震基盤波の算定}

図 7 に示寸深部地盤 model.OPを用いて 2 次元 FEM 解析を行い、 地震基盤波を算定した。算定条件は、地震基盤に SV 波鉛直入射と し、0 5Hz の周波数領域で、JR 新大阪駅地点の地震基盤に対する 工学的基盤位置の伝達関数 $\mathrm{ROP}(\omega)$ を算出した。そして、工学的基 盤位置に対する地震基盤の伝達関数 $\left(1 / R_{\mathrm{OP}}(\omega)\right)$ を、 4.1 節で変換し た工学的基盤波 $\mathrm{W}_{\mathrm{OP}}(\mathrm{t})$ をフーリエ変換した $\mathrm{F}_{\mathrm{OP}}(\omega)$ に掛け合わせ、 フーリエ逆変換することで、地震基盤波 $\mathrm{W}_{\mathrm{sb}}(\mathrm{t})$ (図 8)を算出した (Step2)。

\section{4 深部地盤の応答評価}

図 7 に示す深部地盤 model.A,B,C について 2 次元 FEM 解析を行 った。地震基盤位置に前節で算定した基盤波を SV 波鉛直入射とし、 $0 \sim 5 \mathrm{~Hz}$ の周波数領域で応答計算している。ただし model.C につい ては、SV 波の入射角 $\theta$ を $\theta=10^{\circ}, 20^{\circ}, 30^{\circ}$ とする斜め入射の検討 も行った。工学的基盤位置の $100 \mathrm{~m}$ 間隔の 51 地点について、地震

表 5 深部地盤モデル各層の物性値

\begin{tabular}{|c|c|c|c|c|c|c|c|c|c|c|c|c|c|c|c|}
\hline model & $\begin{array}{c}\mathrm{Vs} \\
(\mathrm{m} / \mathrm{s})\end{array}$ & 300 & 400 & 500 & 600 & 700 & 800 & 900 & 1000 & 1100 & 1200 & 1300 & 1400 & 1500 & 3200 \\
\hline \hline \multirow{2}{*}{$\mathrm{A}$} & $\begin{array}{c}\mathrm{Vp} \\
(\mathrm{m} / \mathrm{s})\end{array}$ & 1600 & 1700 & 1800 & 1900 & 2000 & 2100 & 2300 & 2700 & 3000 & 3200 & 3400 & 3700 & 3800 & 5400 \\
\hline $\begin{array}{c}\rho \\
\left(\mathrm{t} / \mathrm{m}^{3}\right)\end{array}$ & 1.7 & 1.8 & 2.0 & 2.0 & 2.0 & 2.0 & 2.0 & 2.4 & 2.5 & 2.5 & 2.5 & 2.5 & 2.5 & 2.7 \\
\hline \multirow{2}{*}{$\mathrm{B}$} & $\begin{array}{c}\mathrm{Vp} \\
(\mathrm{m} / \mathrm{s})\end{array}$ & 1600 & 1700 & 1800 & 1900 & 2000 & 2100 & 2200 & 2500 & 3000 & 3200 & - & 3700 & 3800 & 5400 \\
\hline $\begin{array}{c}\rho \\
\left(\mathrm{t} / \mathrm{m}^{3}\right)\end{array}$ & 1.7 & 1.8 & 1.9 & 2.0 & 2.0 & 2.0 & 2.0 & 2.2 & 2.5 & 2.5 & - & 2.5 & 2.5 & 2.7 \\
\hline $\mathrm{C}$ & $\begin{array}{c}\mathrm{Vp} \\
(\mathrm{m} / \mathrm{s})\end{array}$ & 1500 & 1700 & 1800 & 1900 & 2000 & 2100 & 2200 & 2400 & 3100 & 3200 & - & 3700 & 3800 & 5400 \\
\hline $\begin{array}{c}\rho \\
\left(\mathrm{t} / \mathrm{m}^{3}\right)\end{array}$ & 1.7 & 1.8 & 1.9 & 2.0 & 2.0 & 2.0 & 2.0 & 2.1 & 2.5 & 2.5 & - & 2.5 & 2.5 & 2.7 \\
\hline \multirow{2}{*}{$\mathrm{OP}$} & $\begin{array}{c}\mathrm{Vp} \\
\left(\mathrm{m}_{\mathrm{s}} / \mathrm{s}\right)\end{array}$ & 1500 & 1700 & 1800 & 1900 & 2000 & 2100 & 2200 & 2400 & 2600 & - & - & - & 3900 & 5400 \\
\hline $\begin{array}{c}\rho \\
\left(\mathrm{m} / \mathrm{m}^{3}\right)\end{array}$ & 1.7 & 1.8 & 1.9 & 2.0 & 2.0 & 2.0 & 2.0 & 2.2 & 2.5 & - & - & - & 2.5 & 2.7 \\
\hline
\end{tabular}


基盤に対する加速度伝達関数 $\mathrm{R}_{\mathrm{x}}(\omega)$ を各モデルで算出した。算出し た伝達関数 $\mathrm{R}_{\mathrm{x}}(\omega)$ を、地震基盤波 $\mathrm{W}_{\mathrm{sb}}(\mathrm{t})$ をフーリエ変換した $\mathrm{F}_{\mathrm{sb}}(\omega)$

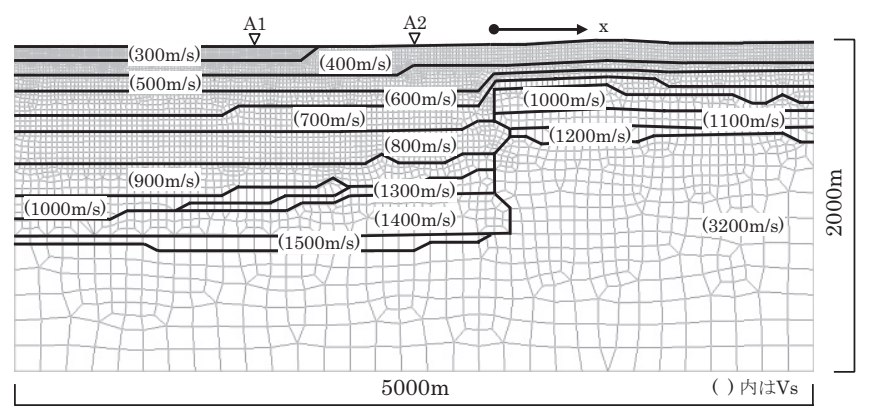

(a) model.A

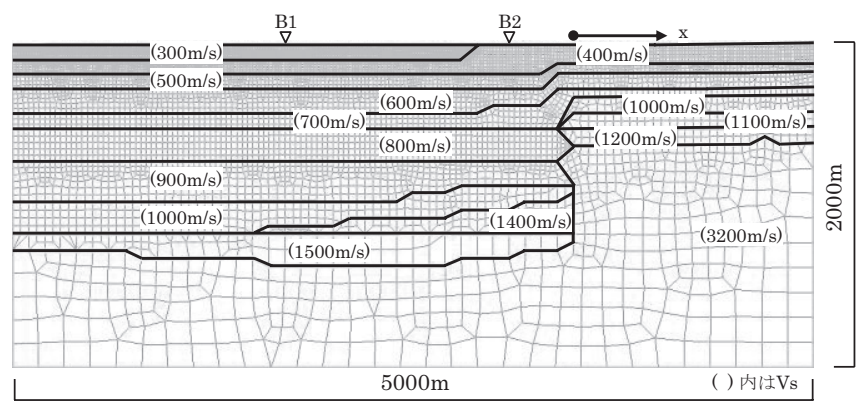

(b) model.B

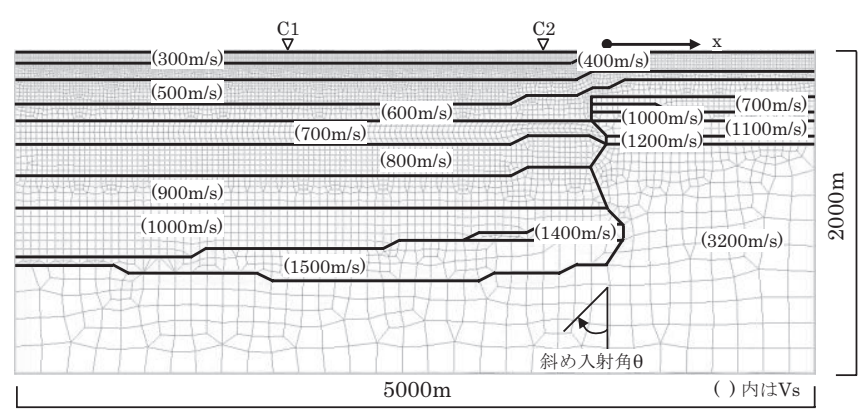

(c) model.C

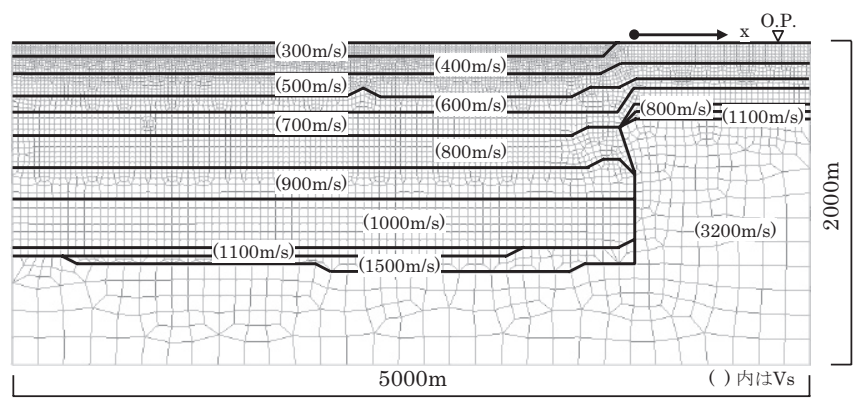

(d) model.OP

図 7 深部地盤モデル

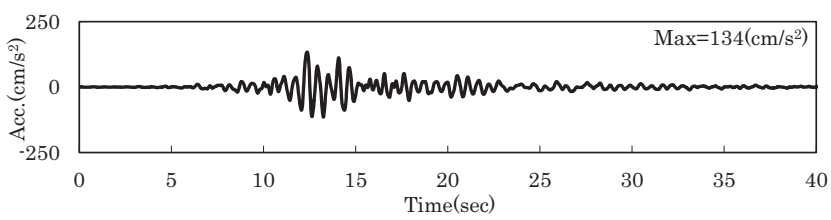

図 8 地震基盤波
に掛け合わせ、フーリエ逆変換することで工学的基盤位置の加速度 応答波形 $\mathrm{W}_{\mathrm{x}}(\mathrm{t})$ を算出した $(\mathrm{Step} 3)$ 。

図 9 に工学的基盤位置の最大加速度応答分布を示す。横軸の $\mathrm{x}=0$ は地中段差位置に相当し、 $\mathrm{x}= \pm 500,1000,1500 \mathrm{~m}$ となるにつれ段差 境界より遠ざかる。図 9 からすべてのモデルにおいて、地中段差の 東側 $(\mathrm{x}$ 座標十側)に比べ西側 $(\mathrm{x}$ 座標一側)の地点で最大振幅が大きく なっていることがわかる。この要因は、地中段差構造によって工学 的基盤位置から地震基盤位置までの深さが段差東側の地点に比心゙、 西側の地点でかなり深くなっているためである。また、特に model.B において B2 地点(x=-800m)、および model.C において C2 地点 $(\mathrm{x}=-600 \mathrm{~m})$ で局所的に最大振幅が大きくなっている。これは、文献 12) 16)にみられる地中段差構造による地震波の干涉によるためであ る。また、 $\mathrm{C} 2$ 地点の方が $\mathrm{B} 2$ 地点に比べより大きく最大振幅が増幅 している要因は、 model.C の段差の高さが model.B に比べ高くなっ ていることにあると考えられる。一方、model.Aでは model.B,Cに 見られるような局所的な最大振幅はあまり大きくない。この要因と して、地震基盤層の上位にある $\mathrm{Vs}_{\mathrm{s}}=1300 \sim 1500(\mathrm{~m} / \mathrm{s})$ の層が厚くなっ ていることで、地震基盤と深部地盤の Vs の差が小さくなり、段差 構造の影響が小さくなっているためであると考えられる。また、 model.A,B では $\mathrm{x}=-1000 \mathrm{~m} \sim-3000 \mathrm{~m}$ と段差境界から離れた地点で、 model.C に比べ PGA が大きくなっていることについても、 $\mathrm{Vs}=1300 \sim 1500 \mathrm{~m}$ の層の厚さが関係していると考えられる。

model.Cにおける斜め入射の検討では、入射角が大きくなるほじ、 最大振幅の分布が東側にずれていく性状を示している。局所的に最

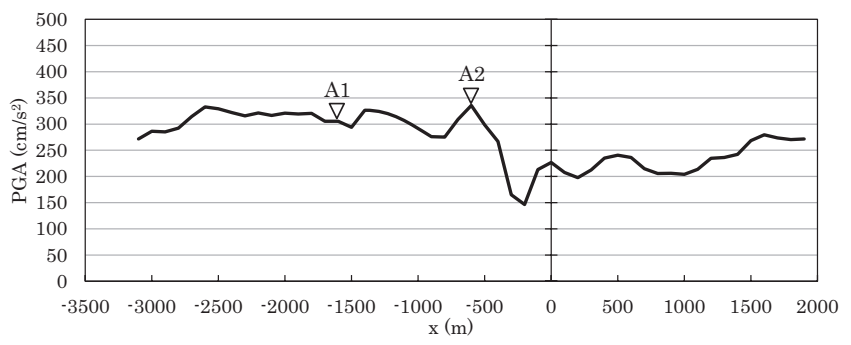

(a) model.A

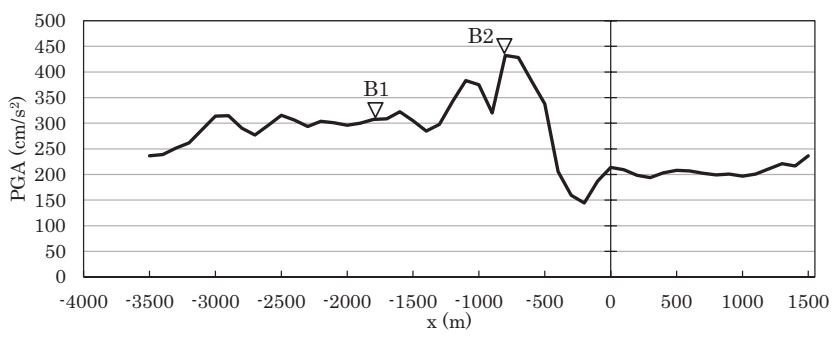

(b) model.B

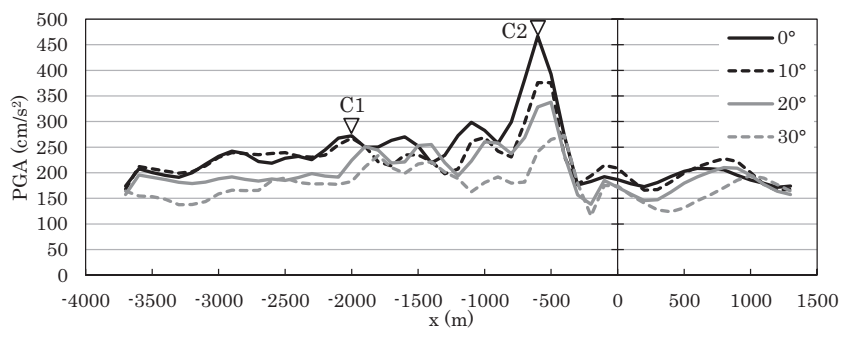

(c) model.C

図 9 工学的基盤位置の最大加速度応答分布 
大振幅が大きくなる地点についても地中段差位置に近づき、最大振 幅が低下する傾向にある。

\section{5. 表層地盤の応答評価}

\section{1 表層地盤のモデル化と計算条件}

図 2 に示寸 $\mathrm{A} 1, \mathrm{~A} 2, \mathrm{~B} 1, \mathrm{~B} 2, \mathrm{C} 1, \mathrm{C} 2$ の 6 地点の表層地盤を 1 次元で モデル化した。B1,C1 地点は、3.1 節でも述べたように被害の集中 した服部地区、庄内地区に位置する。 $\mathrm{A} 1$ 地点は、被害の少なかっ た中部地域に位置し、B1, C1 地点とほぼ経度が等しく、表層地盤デ 一タの存在した地点である。 $\mathrm{B} 2, \mathrm{C} 2$ 地点は 4.4 節の深部地盤の応答 評価で地中段差構造による地震波の干渉により、局所的に最大振幅 が大きくなっている地点である。 B2, C2 地点は吹田市で被害の集中 した南西部に位置する。A2 地点は、被害の少なかった中部地域で、 B2, C2 地点と比較するため段差境界からの距離がほぼ等しい地点を 選んでいる。地盤データに収録されている 6 地点付近の柱状図と $\mathrm{N}$ 值の深度分布 ${ }^{4}$ から作成した表層地盤モデルを表 6 に示す。土の せん断歪み依存性には、土質に応じて表 4 に示した值を用いている。 各層の厚さは $1 \mathrm{~m}$ となるように層分割をした。表層地盤モデルでは、 B1,B2,C1,C2 地点において粘土層がかなり厚くなっている。また、 南に行くにつれて表層地盤の深さが深くなっている。

作成した表層地盤モデルで逐次非線形応答解析を行い、地表面の 応答を評価した (Step4)。入射波には深部地盤の 2 次元 FEM 解析よ り得られた各地点の工学的基盤波を用いて、 $2 \mathrm{E}$ 入力した。

\section{2 表層地盤の応答と被害の考察}

表 7 に、6 地点の表層地盤の逐次非線形応答解析より得られた地 表面の最大加速度(PGA) と最大速度(PGV)を示す。表 7 には、工学 的基盤位置における $\mathrm{PGA}, \mathrm{PGV}$ と JR 新大阪駅地点(O.P)の值も記載 している。市の中部地域に位置する $\mathrm{A} 1, \mathrm{~A} 2$ 地点に比べ、被害の集中 した南部地域に位置する B1,B2,C1の 3 地点では、工学的基盤に対 して地表面で PGV が大きく増幅し、大きな值となっている。さら に、被害集中地域に位置する地点の中でも、深部地盤の段差構造に

表 6 検討地点の表層地盤モデル

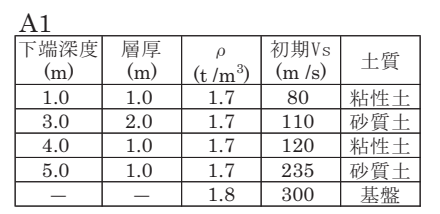

B1

\begin{tabular}{|c|c|c|c|c|}
\hline \begin{tabular}{|c|} 
下端深度 \\
$(\mathrm{m})$
\end{tabular} & $\begin{array}{c}\text { 層厚 } \\
(\mathrm{m})\end{array}$ & $\begin{array}{c}\rho \\
\left(\mathrm{t} / \mathrm{m}^{3}\right)\end{array}$ & $\begin{array}{c}\text { 初期Vs } \\
(\mathrm{m} / \mathrm{s})\end{array}$ & 土質 \\
\hline 1.0 & 1.0 & 1.7 & 70 & 砂質土 \\
\hline 3.0 & 2.0 & 1.7 & 95 & 粘性土 \\
\hline 6.0 & 3.0 & 1.7 & 115 & 砂質土 \\
\hline 7.0 & 1.0 & 1.7 & 115 & 粘性土 \\
\hline 11.0 & 4.0 & 1.7 & 210 & 砂質土 \\
\hline 21.0 & 10.0 & 1.7 & 180 & 粘性土 \\
\hline 24.0 & 3.0 & 1.7 & 280 & 砂質土 \\
\hline- & - & 1.8 & 300 & 基盤 \\
\hline
\end{tabular}

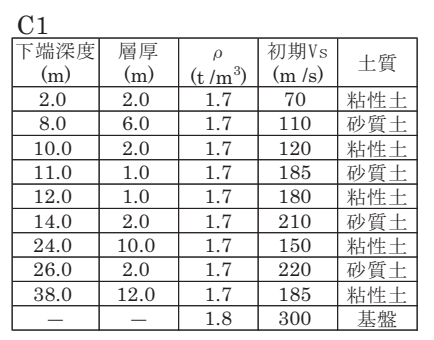

よる局所的な増幅が見られた $\mathrm{B} 2$ 地点において、地表面での PGA が 最も大きい。一方、 $\mathrm{C} 1, \mathrm{C} 2$ の 2 地点では、PGA が工学的基盤位置 に対して地表面で低減している。これは、2 地点の表層地盤では粘 土層が厚く、特に $\mathrm{C} 1$ 地点は表層地盤の深さが $38 \mathrm{~m}$ と他の地点に比 べかなり深くなっていること、 $\mathrm{C} 2$ 地点は工学的基盤位置での入力 地震動が大きいことにより、地盤の非線形化が進んだためである。

6 地点の地表面と工学的基盤位置の加速度波形から、減衰定数 $\mathrm{h}=5 \%$ で算定した加速度応答スペクトルを図 10 に示す。 6 地点とも 約 0.6(s)が卓越周期となっている。一方、周期 1 2(s)の成分につい ては、A1,A2 地点で地表面と工学的基盤位置でほぼ差がないのに対 して、B1,B2,C1,C2の 4 地点では地表面で増大している。図 11 に $\mathrm{A} 1, \mathrm{~B} 1, \mathrm{C} 1$ の 3 地点の最大せん断歪み分布を示す。粘土層が厚くな っている $\mathrm{B} 1, \mathrm{C} 1$ 地点では、特に粘土層とその上位にある砂質土層の 境界で最大せん断歪みが大きくなっている。したがって、 $\mathrm{B} 1, \mathrm{~B} 2, \mathrm{C} 1, \mathrm{C} 2$ の 4 地点で見られる周期 1 2(s)の成分の増幅は、 4 地

表 7 検討地点の PGA と PGV

\begin{tabular}{|c|c|c|c|c|}
\hline \multirow{2}{*}{ 地点 } & \multicolumn{2}{|c|}{$\mathrm{PGA}\left(\mathrm{cm} / \mathrm{s}^{2}\right)$} & \multicolumn{2}{c|}{$\mathrm{PGV}(\mathrm{cm} / \mathrm{s})$} \\
\cline { 2 - 5 } & 地表面 & 工学的基盤 & 地表面 & 工学的基盤 \\
\hline A1 & 343 & 305 & 41 & 38 \\
\hline A2 & 382 & 336 & 39 & 37 \\
\hline B1 & 336 & 308 & 55 & 36 \\
\hline B2 & 446 & 432 & 64 & 46 \\
\hline C1 & 223 & 272 & 41 & 29 \\
\hline C2 & 282 & 467 & 46 & 48 \\
\hline O.P & 229 & 174 & 23 & 19 \\
\hline
\end{tabular}
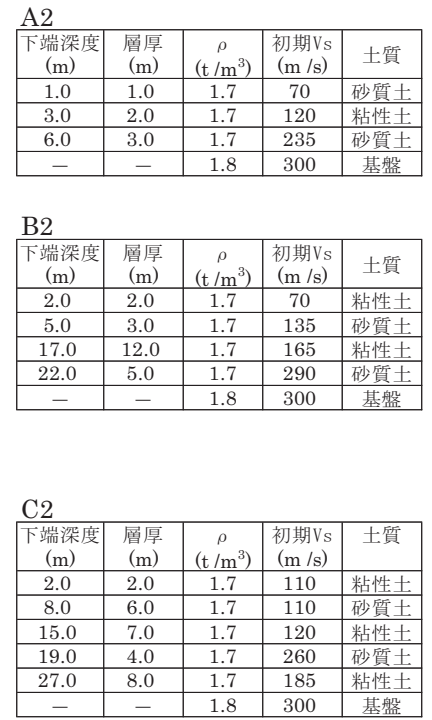

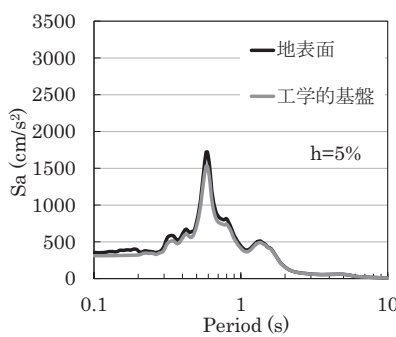

(a) A1

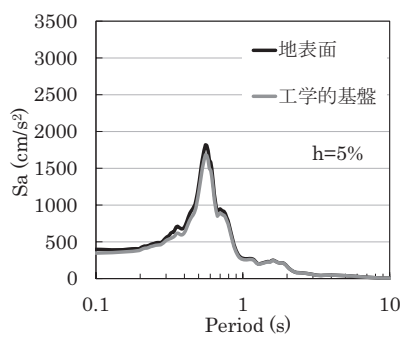

(b) $\mathrm{A} 2$

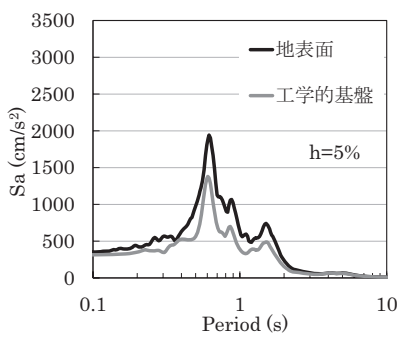

(c) B1

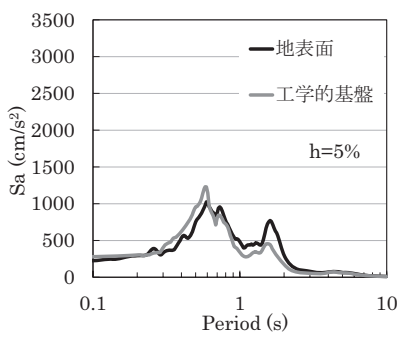

(e) $\mathrm{C} 1$

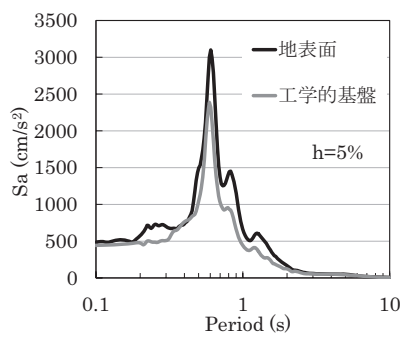

(d) B2

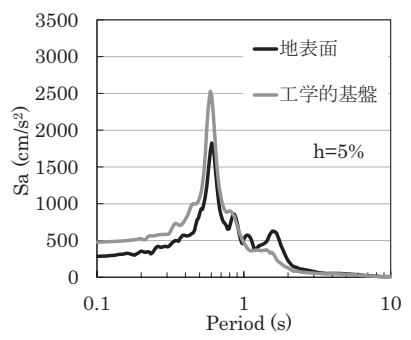

(f) $\mathrm{C} 2$

図 10 地表面と工学的基盤位置の加速度応答スペクトル 
点の表層地盤を構成する厚い沖積層が影響していることがわかる。 この表層地盤により増大した周期 1 2(s)の加速度成分は、古い木造

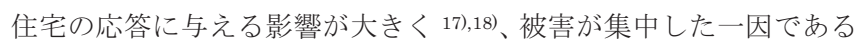
と考えられる。

次に、表層地盤の地震動増幅特性が木造住宅の被害に与えた影響 をさらに検討するため、 A1,B1,C1 地点の地表面の加速度応答スペ クトルから、林 19)の提案する性能等価加速度応答スペクトルに基づ き、木造住宅の最大応答変形角 $\mathrm{R}_{\max }$ を推定する。木造住宅の性能等 価加速度応答スペクトルは、住宅を基礎固定の等価 1 質点系モデル に置換し、その復元力特性を降伏変形角 $1 / 100$ のバイリニア型と仮 定して、与えられた変形角 $\mathrm{R}$ を住宅の変形限界としたときの地震荷

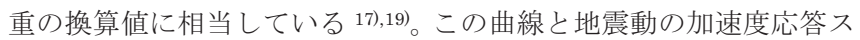
ペクトルとの交点から、木造住宅の最大応答変形角 $\mathrm{R}_{\max }$ および最大 応答に最も寄与する地震動の周期成分が推定される。本検討では、 2 階建て木造住宅の等価高さを $\mathrm{H}_{\mathrm{e}}=4.5 \mathrm{~m}$ として、降伏せん断力係数 $\mathrm{C}_{\mathrm{y}}=0.05 \sim 1.0$ で変化させ、1/R が $5 \sim 100$ までの範囲を示した性能等 価加速度応答スペクトルを、図 12 に付き線で示す。また、図 12 には JMA 神戸地点の NS 成分の観測記録の加速度応答スペクトル も併記している。図 12 から、豊中市で被害の集中した地域に位置

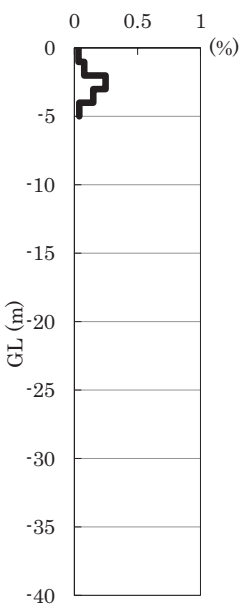

(a) A1

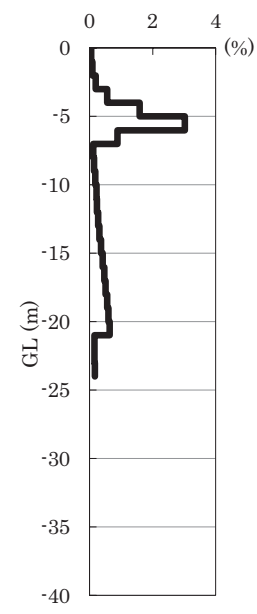

(b) B1

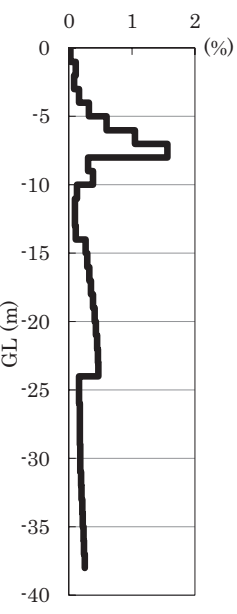

(c) $\mathrm{C} 1$
図 11 最大せん断歪みの深さ分布

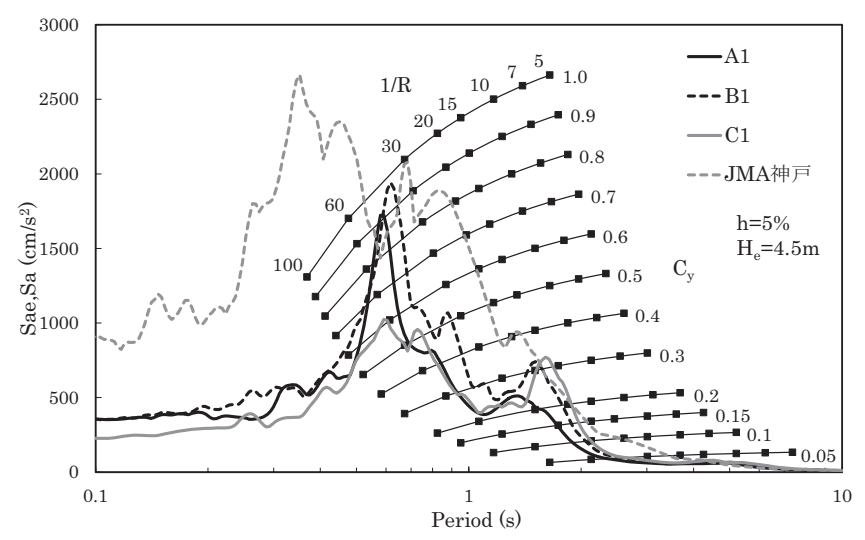

図 $12 \mathrm{~A} 1, \mathrm{~B} 1, \mathrm{C} 1$ 地点で推定した地震動および JMA 神戸地点の観測記録(NS 成分) と 木造住宅の性能等価加速度応答スペクトルの比較
する $\mathrm{B} 1, \mathrm{C} 1$ 地点では、 $\mathrm{C}_{\mathrm{y}}=0.2,0.3$ と比較的耐力の低い木造住宅で $R_{\max }$ が 1/20 1/15 程度と大きな值となる。一方、被害の少なかった 地域に位置する $\mathrm{A} 1$ 地点では、 $\mathrm{C}_{\mathrm{y}}$ が 0.3 以下においても、 $\mathrm{R}_{\max }$ は 1/60 1/30 程度である。この差は、周期 1 2(s)成分のピークの位置 と大きさによるものである。図 10 から、この周期 1 2(s)成分のピ 一クの差は、深部地盤の増幅特性による工学的基盤波の特性と、表 層地盤の増幅特性によるものである。また、図 12 において、JMA 神戸では $\mathrm{C}_{\mathrm{y}}$ が 0.8 以下の木造住宅で $\mathrm{R}_{\max }$ は $1 / 20$ 程度であるが、 $\mathrm{B} 1, \mathrm{C} 1$ 地点では耐力の低い木造住宅において同程度の変形が生じて おり、豊中市において耐力が低いと考えられる古い木造住宅に被害 が多かったという報告 2),7) と整合する。

さらに、6 地点の地表面の応答レベルを検討するため、兵庫県南 部地震時に兵庫県内と大阪府内の地表で観測された記録 9) との比較 を行う。検討地点と周辺観測地点の位置関係を図 13 に示す。兵庫 県内の観測地点は神戸市と尼崎市に位置している。図 14 には、周 辺観測地点と 6 地点の PGA と PGV の関係を示す。なお、観測記録 の $\mathrm{PGA}$ と $\mathrm{PGV}$ は水平 2 成分のうち大きな方の值である。 $\mathrm{B} 1, \mathrm{~B} 2, \mathrm{C} 1, \mathrm{C} 2$ の 4 地点の地表面の応答は、文献 20)で木造住宅の被災 地の地震動の特徵の一つとされている $\mathrm{A} / \mathrm{V}=6 \sim 8$ の付近に分布して いる。そして、B1, B2, C1, C2 地点は、被害の少なかった $\mathrm{A} 1, \mathrm{~A} 2$ 地 点や他の大阪府内の観測記録と比較して、 $\mathrm{A} / \mathrm{V}$ が低い傾向にある。

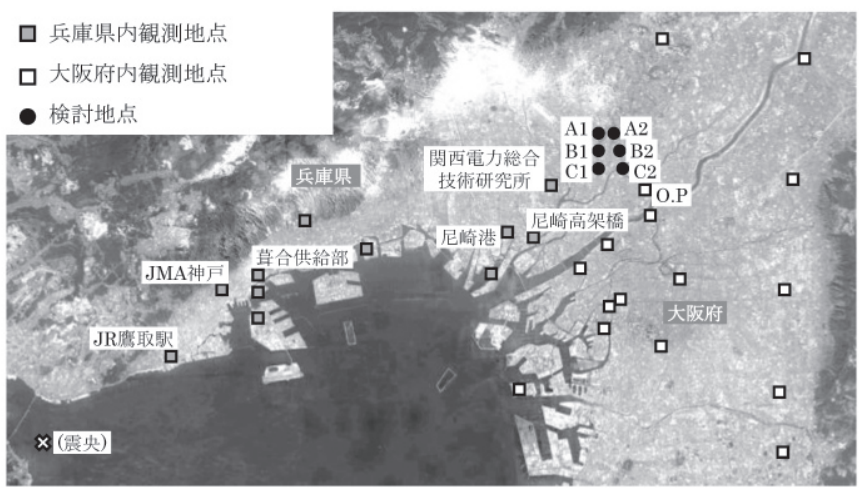

図 13 検討地点と周辺観測地点の位置関係

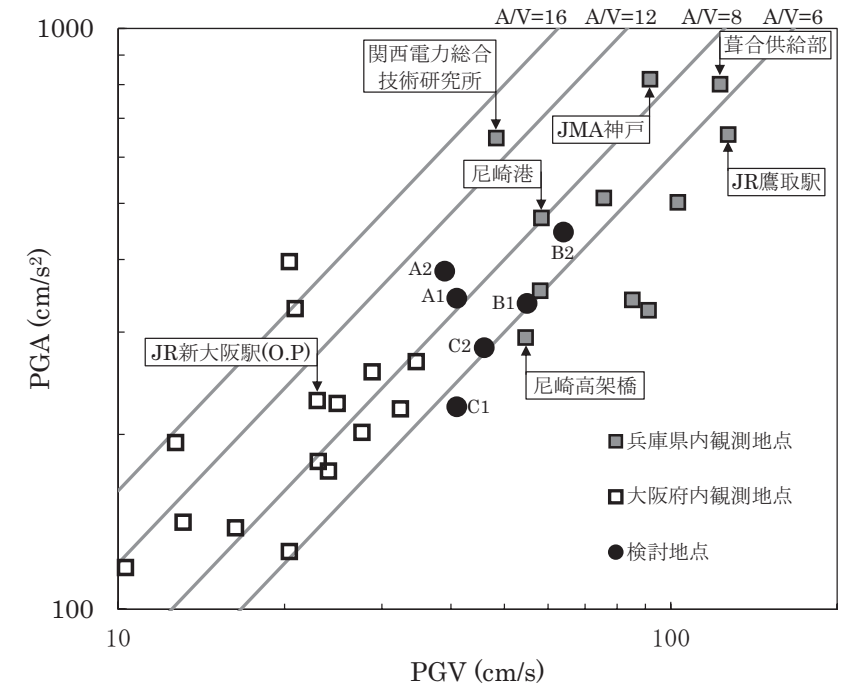

図 $14 \mathrm{PGA}$ と $\mathrm{PGV}$ の関係 


\begin{tabular}{|c|c|c|c|c|}
\hline \multicolumn{2}{|r|}{ 観測点 } & $\begin{array}{l}\text { PGA } \\
\left(\mathrm{cm} / \mathrm{s}^{2}\right)\end{array}$ & $\begin{array}{l}\mathrm{PGV} \\
(\mathrm{cm} / \mathrm{s})\end{array}$ & $\begin{array}{c}\text { 全半壊率 } \\
(\%)\end{array}$ \\
\hline 神 & JR鷹取駅 & 657 & 127 & 81.0 \\
\hline 戸 & \begin{tabular}{|l} 
JMA神戸 \\
\end{tabular} & 818 & 92 & 58.6 \\
\hline 市 & 莫合供給部 & 802 & 123 & 57.6 \\
\hline 尼 & 関西電力総合技術研究所 & 648 & 48 & 31.8 \\
\hline 崎 & 尼崎高架橋 & 294 & 49 & 23.1 \\
\hline 市 & 尼崎港 & 472 & 58 & 19.0 \\
\hline
\end{tabular}

注) PGA,PGVは水平 2 成分のうち大きな方の值

また、6 地点の PGA と PGV は兵庫県南部地震の神戸市などの被災 中心地域と、大阪府の他の市町村における観測記録の中間に分布し ている。表 8 に、兵庫県内の観測記録のうちで、その周辺の家屋の 被害率が報告されているものを示す 21 。表 2 に示した服部地区と庄 内地区の木造家屋の全半壞率と比較して、神戸市内の全半壊率はか なり大きな值であり、豊中市に隣接する尼崎市内についても服部地 区と庄内地区よりも大きい。図 14 から神戸市内、尼崎市内、服部 庄内地区 $(\mathrm{B} 1 \cdot \mathrm{C} 1)$ の順に $\mathrm{PGA}, \mathrm{PGV}$ が小さくなる傾向にあり、各地 区の全半壞率とある程度整合している。以上から、兵庫県南部地震 で被害が集中した豊中市の南部地域の地震動の大きさは、神戸市や 尼崎市の地震動に比べると小さいが、大阪府の他の市町村における 地震動よりも大きく、被害集中に影響を与えたと考えられる。

\section{6. まとめ}

兵庫県南部地震で被害集中の飛び地となった大阪府豊中市の被害 状況と地形・地質の特徵について分析した。特に被害が集中した市 の南部地域と、比較的被害の少なかった中部地域を対象に地盤モデ ルを作成し、地震増幅特性について検討した。そして得られた被害 集中地域の地震動特性を分析し、被害集中の原因について検討を行 った。これらの結果から得られた知見を以下にまとめる。

1) 兵庫県南部地震の際、地理的に兵庫県阪神地区に隣接する大阪府 豊中市の南部地域とその東側に位置する吹田市の南西部地域で 古い木造住宅の被害が集中した。この地域の深部地盤には、上町 断層帯による地中段差構造が存在し、吹田市の南西部地域に地中 段差構造による地震波の干渉で局所的に振幅が増大寸る地点が あった。

2)さらに、被害の集中した南部地域の表層地盤は、中部地域と比較 して軟弱な粘土層がかなり厚くなっており、最大速度が大きくな った。また、厚い沖積層の影響により周期 1 2(s)の加速度成分が 増大したため、被害集中の一因となったと考えられる。

3)被害集中地域で解析により求めた地表の地震動から性能等価加 速度応答スペクトルに基づき、被害集中地域の木造住宅の最大応 答変形角 $\mathrm{R}_{\max }$ を推定すると、 $\mathrm{C}_{\mathrm{y}}=0.2,0.3$ と比較的耐力の低い木造 住宅で $R_{\max }$ が 1/20 1/15 程度と大きな值となった。

4) 被害集中地域における地表の地震動の大きさは、神戸市や尼崎市 の地震動に比べると小さいが、大阪府の他の市町村における地震 動よりも大きいものであることを確認した。また、 $\mathrm{A} / \mathrm{V}$ は木造住 宅の被災地の地震動の特徴の一つとされている $6 \sim 8$ 程度の值と なった。

\section{謝辞}

本研究の深部地盤の 2 次元 FEM 解析では、東京理科大学の永野 正行教授にご教示頂きました。ここに記して、感謝の意を表します。 一部、図の作成で Google Earth を利用させて頂きました。

\section{参考文献}

1）内閣府：阪神・淡路大震災の概要, http://www.bousai.go.jp/1info/ kyoukun/hanshin_awaji/earthquake/index.html, 2011.11.1参照

2）天国邦博，呂恒偀，望月利男：阪神・淡路大震災における豊中市の被害状 況に関する一考察，地域安全学会論文報告集(5), 1995.11

3) 地震調查研究推進本部地震調查委員会: 海溝型地震の長期評価の概要, http://www.jishin.go.jp/main/choukihyoka/kaikou.htm, 2011.11.1 参照

4） KG-NET ・ 関西圈地盤情報協議会, 関西圈地盤 DB 運営機構 : - 2010 年度 版-関西圈地盤情報データベース CD-ROM, 2010

5）独立行政法人, 産業技術総合研究所, 地質調査総合センター: 大阪堆積盆 地 3 次元地盤構造モデル CD-ROM, 2004.4

6）豊中市：阪神淡路大震災・豊中市の記録, 1997.3

7) 篠崎亘, 谷村恭, 高田直俊 : 阪神・淡路大震災における豊中市の被害と地 盤，土と基礎 44(2), pp.45-47, 1996.2

8）吹田市: 兵庫県南部地震による被害と都市地盤に関する基礎調査報告書, 1996.3

9) 日本建築学会兵庫県南部地震特別研究委員会, 特定研究課題 1-SWG1, 日本建築学会近畿支部而震構造研究部会 : 1995 年兵庫県南部地震強震記 録資料集, 1996.1

10）太田裕, 後藤典俊: $\mathrm{S}$ 波速度を他の土質的諸指標から推定する試み, 物理 探鉱，第 29 巻，第 4 号, pp.31-41, 1976.8

11）古山田耕司, 宮本裕司, 三浦賢治: 多地点での原位置採取試料から評価し た表層地盤の非線形特性, 第 38 回地盤工学会研究発表会, pp.2077-2078, 2003.7

12）永野正行, 大野晋, 古山田耕司, 加藤研一：兵庫県南部地震時の神戸市 内における基盤地震動および地盤増幅特性, 日本建築学会構造系論文集, No.511, pp.77-84, 1998.9

13）永野正行 : 2 次元盆地端部構造の地震動増幅と表面波の干渉, 日本建築 学会構造系論文集, No.552, pp.85-92, 2002.2

14）源栄正人, 永野正行：深部不整形地下構造を考慮した神戸市の地震動の 増幅特性解析, 一兵庫県南部地震における「震災の帯」の解釈 - , 日本 建築学会構造系論文集, No.488, pp.39-48, 1996.10

15）川瀬博, 松島信一: 三次元盆地構造を考慮した 1995 年兵庫県南部地震の 神戸地域における強震動シミュレーション, 日本建築学会構造系論文集, No.514, pp.111-118, 1998.12

16）永野正行, 東山恵: 深部地盤の地中段差近傍における地震動増幅特性, 日 本建築学会構造系論文集, No.643, pp.1585-1594, 2009.9

17）時松孝次, 新井洋, 関口徹 : 2004 年新潟県中越地震時に表層地盤の非線 形震動増幅特性が小千谷の木造住宅被害に与えた影響, 日本建築学会構 造系論文集, No.620, pp.35-42, 2007.10

18）松島信一, 川瀬博 : 1995 年兵庫県南部地震での神戸市域における強震動 と木造建物被害の再評価, 構造工学論文集, Vol.55B, pp.537-543, 2009.3

19）林康裕：性能等価応答スペクトルに基づく建築物の地震荷重評価, 第 11 回日本地震工学シンポジウム, pp.651-656, 2002

20）森井雄史, 林康裕: 表層地盤の地震動増幅特性と入射地震動特性が木造 建物応答に及ぼす影響, 日本建築学会構造系論文集, No.568, pp.75-82, 2003.6

21）境有紀, 神野達夫, 䋶纈一起: 震度の高低によって地震動の周期带を変化 させた震度算定法の提案, 日本建築学会構造系論文集, No.585, pp.71-76, 2004.11

(2011年12月 8 日原稿受理, 2012年 6 月22日採用決定) 